adaptation training]. Osvitolohichnyi dyskurs: elektronne naukove fakhove vydannia [Educological discourse: Scientific electronic professional edition], no. 2 (29), pp. 132-142.

4. Novyk, I. (2020). «SELF-BOOK» osobystisno-profesiinoho zrostannia maibutnoho pedahoha [ «SELF-BOOK» personal and professional growth of the future teacher]. Osvitolohichnyi dyskurs: elektronne naukove fakhove vydannia [Educological discourse: Scientific electronic professional edition], no. 3 (30), pp. 206-220.

5. Novyk, I., Venhlovska, O., \& Kuzemko, L. (2019). Vykorystannia internetresursiv $\mathrm{v}$ osobystisno-profesiinomu rozvytku maibutnikh pedahohiv [The use of Internet resources in the personal and professional development of future teachers]. Pedahohichni nauky: teoriia, istoriia, innovatsiini tekhnolohii [Pedagogical sciences: theory, history, innovative technologies], no. 4 (88), pp. 3-17.

6. Shepelova, M. (2020). Psykholohichnyi suprovid osobystisno-profesiinoho zrostannia maibutnikh fakhivtsiv doshkilnoi haluzi [Psychological support of personal and professional growth of future professionals in the preschool industry]. Doshkilna osvita $v$ konteksti idei Novoi ukrainskoi shkoly: zbirnyk naukovykh prats [Preschool education in the context of the ideas of the New Ukrainian school: a collection of scientific papers]. Khmelnytsk: FOP Melnyk, pp. 454-464.

\title{
STUDENTS’ FOREIGN LANGUAGE SPEECH ACTIVITY AT HIGHER TECHNICAL EDUCATIONAL INSTITUTION
}

\section{Kateryna Halatsyn ${ }^{1}$ Olha Yaroshenko ${ }^{2}$}

DOI: https://doi.org/10.30525/978-9934-26-002-5-3

The entry of Ukraine into the pan-European economic and educational space actualize the problem of speech activity in foreign language communication. Foreign language communication becomes an essential component of the future professional activity of a specialist. The relevance of the problem is also determined by the existence of a contradiction between the social order for a highly qualified specialist who speaks a foreign language and can use it in his professional activities and the low level of training of graduates of higher education in a foreign language.

According to researchers, the motivational level is represented by a complex interaction of the aspirations, motives and goals of speech acts as a further result of it. Several internal and external motives stimulate activities.

\footnotetext{
${ }^{1}$ Igor Sikorsky Kyiv Polytechnic Institute, Ukraine

${ }^{2}$ Igor Sikorsky Kyiv Polytechnic Institute, Ukraine
} 
For our analysis, it is essential to note its internal motive. Therefore, this implies the creation of a situation that would motivate the emergence and development of communicative and cognitive needs to master the communication skill.

The research-oriented level of speech activities covers the conditions of activity, the allocation of an object, raising funds, activity instruments and the like. The research-oriented level of speech activities is also the implementation level of the selection of means and methods formation and expression of thought in the process of speech communication. At this level, there is programming and internal organization of a substantive, meaningful plan of speech activities. The executive level of speech activity can be externally pronounced and unimpressed. An essential part of the substantive content of the activity is the result, which usually manifested in a particular reaction of others to the product of this activity. Therefore, in receptive speech activities, the result of the hearing is an understanding of the content of the text and subsequent broadcasting.

The text material for the reception should not only be interesting, but also correspond to the age and intellectual capabilities of students and the like. It is important to note that hearings, like reading, can be conducted for various purposes. Thus, the hearing may aim at obtaining the most general understanding of the content of the foreign language text. The purpose of the training hearing may be a complete and accurate understanding of all the information contained in the text. The realization of this goal, of course, involves knowledge of all language phenomena found in the text [4, p. 34-40].

It is generally accepted to distinguish three levels of development of foreign-language communicative competence minimum (elementary), medium (independent) and maximum (experimental). The task of reaching the maximum level can only apply in a language university. Even the intermediate level should serve as a target for various optional courses, which follow the main course and intended for in-depth training.

Taking into account the above, a vocational-oriented approach to mastering foreign language speech activities is being updated, which involves the formation of students' ability to communicate in a foreign language, taking into account the specifics of professional vocabulary. Therefore, the study of a foreign language at a higher school, in our opinion, is based on the needs of students under the chosen speciality and should go in the following areas: work on particular texts taking into account the professional interests of students; the study of special topics for the development of oral speech, the active use of its monological form, contributes to the formation of students' ability to make a description, express an idea, convey an information message 
and the like; study of the lexical minimum in the speciality; Foreign language communication in the field of future professional activity [1, p. 78-79].

The integration of such didactic principles as activity, communicationprofessional orientation, individualization is decisive in this process. In preparing students for speech activities in foreign language communication, we offer to organize variable training. It provides, first, for the presence of a formed motivational sphere for mastering foreign-language speech activities and self-control over the formation of their integrated communication skills and skills.

The study of speech activity gave grounds to determine psychological and pedagogical characteristics: structural organization (motivationalmotivational, indicative-research, executive level), subject content (opinion). The result of speech activity is the corresponding action of participants in speech communication. Taking into account the psychological and pedagogical characteristics of speech activities contributes to qualitative changes in proficiency in foreign language speech activities; involuntary bringing a new, previously unfamiliar language phenomenon under the already known language rules; ease and arbitrariness of combinatorial variants of thought expression and freedom of interpretation of the received speech message given under different communication conditions; improved quality and time characteristics of all speech activities. Knowledge of the internal structure of speech activities is significant for both the teacher and the student.

\section{References:}

1. Bolotina, N. (2010). Soderzhanie professional'no-orientirovannogo obuchenija inostrannomu jazyku $\mathrm{v}$ nejazykovom vuze [The content of the professional focused training in a foreign language in not language higher education institution]. Proceedings of the IV International Theoretical and Practical Conference to the 89 anniversary of formation of Belorusky state university «Cross-cultural communication and the professional focused training in foreign languages», (pp. 78-79) the Collection of scientific works. Minsk: Prod. BGU center. (in Russian)

2. Zimnyaya, I. (1977). K voprosu o psihologicheskih mehanizmah receptivnyh vidov rechevoj dejatel'nosti [To a question of psychological mechanisms of receptive types of speech activity]. Foreign languages at the higher school. Moskow: The higher school, vol. 12, pp. 106-116. (in Russian)

3. Ksenofontova, A. (2002). Teoreticheskie osnovy pedagogicheskogo konstruirovanija rechevoj dejatel'nosti [Theoretical bases of pedagogical designing of speech activity]. Bulletin of regional public institution, iss. 8, pp. 4-9. (in Russian)

4. Homyak, A., \& Klish, P. (2010). Movlennyeva diyal'nist' yak zasib verbal'noho spilkuvannya [Speech activity as means of verbal communication]. The scientific bulletin of VNU named after Lesya Ukrainka, Series: Pedagogical sciences, iss. 23, pp. 34-40. (in Ukrainian) 